\title{
Resenha: Tábula Rasa: A Negação Contemporânea da Natureza Humana
}

\author{
Lílian Erichsen Nassif ${ }^{1}$ \\ Universidade Federal de Minas Gerais
}

\section{Book Review: The Blank Slat: The Modern Denial of Human Nature}

Numa época de intensas discussões sobre a ética que envolve nosso patrimônio genético e as pesquisas com células-tronco, é publicado “Tábula Rasa”. Nesse livro polêmico, através do debate entre natureza e criação, o psicólogo canadense Steven Pinker pretende desfazer o mito da tábula rasa, segundo ele tão presente na atualidade. Mito que distorce política e emocionalmente as descobertas da ciência sobre a natureza humana a qual, sendo parcialmente biológica, implica a existência de diferenças genéticas da personalidade, dos sexos, dos comportamentos violentos, etc. Para o autor a compreensão disso nos ajudaria a melhorar a adaptação da nossa espécie, ao contrário do que pensam os mais temerosos, ou seja, que esta visão acarretaria um retorno à eugenia e à discriminação. Com isso, ele alerta para o fato de os tradicionais alinhamentos políticos precisarem mudar diante da evolução dos conhecimentos sobre os seres humanos. Tenta nos mostrar que a natureza humana pode ser um problema, mas também a solução.

Apresentado em 20 capítulos distribuídos em seis partes, o livro tem como tema principal a natureza humana, ou seja, "uma dotação de faculdades cognitivas e emocionais que é universal nos espécimes sadios do Homo sapiens" (Pinker, 2004 , p. 200). Baseia-se na opinião do autor sobre a existência de uma natureza humana universal, na qual a mente deve parte de sua estrutura a informações no genoma, sendo moldada pela seleção natural com uma lógica comum a todas as culturas e não podendo ser apagada ou redesenhada a partir do zero. Mas segundo Pinker, existe "a teoria oficial" que se opõe a esse entendimento, embasada nas três teorias que intitulam a primeira parte do livro: a tábula rasa, o bom selvagem e o fantasma na máquina. De autoria de Locke, Rousseau e Descartes, respectivamente, essas teorias são conhecidas como empirismo, romantismo e dualismo. O autor afirma que, com frequiência, elas são encontradas juntas e ainda figuram nos tempos atuais para justificar a separação entre cultura e biologia, tornando a natureza humana um tabu. Otto Jespersen, um importante lingüista, é o primeiro de uma lista de teóricos citados para ilustrar a presença dessas idéias nas teorias que embasam a psicologia moderna.

Do terceiro ao quinto capítulo, encontramos um resumo da atual argumentação científica a favor de uma natureza humana complexa, cujas implicações são examinadas no decorrer do livro. É apontado como as ciências da mente, cérebro, genes e evolução, ao trazer uma nova compreensão da natureza humana, fazem cair por terra a separação entre

1 Endereço: Alameda dos Coqueiros, 1144. Bairro São José, Pampulha, Belo Horizonte, MG, Brasil 31275-170.

E-mail: lilian.erichsen@terra.com.br matéria e mente, físico e mental, biologia e cultura, natureza e sociedade, ciências e ciências sociais e humanas. São propostas quatro pontes que ligariam a biologia e a cultura: a ciência cognitiva, a neurociência cognitiva, a genética comportamental e a psicologia evolucionista. O capítulo seguinte traz uma discussão sobre cultura e natureza humana, e inicia-se com uma parte do conto "A loteria da Babilônia" de Jorge Luis Borges, para ilustrar como a cultura costuma ser entendida: "um conjunto de papéis e símbolos que misteriosamente recaem sobre o indivíduo” (Pinker, 2004, p. 91). Pinker propõe uma alternativa evolutiva a essa crença: as culturas dependem de um conjunto de circuitos neurais responsáveis pela aprendizagem, os quais fundamentam o comportamento das pessoas, permitindo-lhes serem membros competentes da cultura. Com o intuito de demonstrar que algumas hipóteses não são confirmações da doutrina da tábula rasa e sim produtos dela, o último capítulo da primeira parte retrata três questões científicas interpretadas como obstáculos à possibilidade de uma natureza humana complexa, quais sejam: o Projeto Genoma Humano, o conexionismo e os estudos da plasticidade neural. $\mathrm{O}$ autor refuta as três perspectivas.

A segunda parte do livro expõe as reações políticas da direita e da esquerda, motivadas pelas novas ciências da natureza humana. No Capítulo 6, o autor descreve as "lorotas" produzidas como reação às novas idéias sobre a natureza humana e, depois, no Capítulo 7, mostra como essas reações nasceram de um imperativo moral de defender a tábula rasa, o bom selvagem e o fantasma na máquina. Após citar vários autores que se revoltaram contra as teorias da natureza humana, discute algumas razões para as críticas a essas teorias terem ido além do debate acadêmico, transformando-se em deturpações e acusações caluniosas de carnificina. Pinker aposta que a hostilidade da direita em relação às ciências da natureza sucumbirá diante dos crescentes indícios de que a teoria da evolução é correta. Critica a hostilidade da esquerda radical que, segundo ele, marca a vida intelectual moderna (establishment acadêmico) e utiliza o dogma da biologia desvinculada da ordem social humana como salvo-conduto para enfrentar as turbulências políticas da academia.

$\mathrm{Na}$ terceira parte, Pinker diz que questões como ideais de igualdade, progresso, responsabilidade e valores pessoais devem ser tratadas sem medo e aversão, pois uma concepção renovada de significados e moralidade sobreviverá à extinção da tábula rasa. Seus argumentos giram em torno da explicação a respeito dos quatro principais temores sobre a natureza humana: medo da desigualdade, medo da imperfectibilidade, medo do determinismo e medo do niilismo. Para cada um desses temores é dedicado um capítulo, nos quais são explicadas suas bases e apontadas quais afirmações sobre a 
natureza humana estão em jogo e por que se julga que elas têm implicações insidiosas. Em seguida, é demonstrado que, em cada caso, a lógica é falha. É argumentado, ainda, que o receio de a tábula não ser rasa é derivado do fato de os indivíduos diferirem inatamente em seus talentos, habilidades e interesses, o que nos remeteria a três males: o preconceito, o darwinismo social e a eugenia.

A quarta parte do livro apresenta, em quatro capítulos, o que é a natureza humana e que diferença ela faz em nossa vida pública e privada, trazendo algumas idéias atuais sobre as especificações estruturais das faculdades humanas básicas. O primeiro capítulo dessa parte trata das suposições sobre a cognição que fundamentam movimentos relativistas recentes na vida intelectual, e lança luzes sobre as raízes do preconceito, a mídia e as artes. $\mathrm{O}$ argumento é introduzido através de exemplos do estudo da percepção. O segundo capítulo mostra que devemos adicionar os fatores cognitivos aos fatores morais, empíricos e políticos envolvidos nos debates sobre a natureza humana. No próximo capítulo, é discutido o altruísmo, a diferença entre nossos sentimentos pelos familiares e não familiares, a conscienciosidade, a aquiescência, as tendências neuróticas, a psicopatia e os comportamentos criminosos, os quais seriam substancialmente determinados por fatores genéticos modificados evolutivamente. No último capítulo desta parte, o autor salienta o medo que as pessoas têm de que uma compreensão biológica da mente conduza ao niilismo moral. Mas demonstra por meio de uma explicação evolucionista das emoções que isso não precisa ocorrer, pois o senso moral seria um dispositivo formado de partes mais antigas do cérebro primata e moldado pela seleção natural para realizar um fim. Além disso, existiriam três esferas de moralidade, cada qual moldando os julgamentos morais de um modo diferente: a ética da autonomia, a ética da comunidade e a ética da divindade.

$\mathrm{Na}$ quinta parte do livro, são abordados cinco temas, em cinco capítulos respectivos: política, violência, gênero, crianças e artes. O primeiro deles aborda as conexões intelectuais entre as ciências da natureza humana e a brecha entre as filosofias políticas de direita e de esquerda. Para o autor, não podemos entender as controvérsias sobre mente, cérebro, genes e evolução sem compreender seu paralelo com antigas divisões políticas. Sobre a violência, Pinker diz que muitos intelectuais negam o olhar evolucionista, preferindo adotar a ilusão do bom selvagem, segundo a qual a violência é um produto do aprendizado ou um agente patogênico externo a nós. Apesar de concordar que a violência é um problema social e político, além de biológico e psicológico, o autor descreve a lógica da violência e discorre sobre as possíveis razões da evolução dos pensamentos e emoções vinculados a ela. O objetivo do capítulo sobre gênero é elucidar a relação entre a biologia da natureza humana e as atuais controvérsias sobre gênero. Além de apresentar duas teorias evolucionistas sobre o estupro, Pinker aponta 12 indícios da natureza humana que provam a diferença entre homens e mulheres. No capítulo sobre crianças, são descritas três leis da genética comportamental, consideradas pelo autor como as descobertas mais importantes na história da psicologia. Somos introduzidos numa discussão sobre a hereditariedade de características mentais (primeira lei), a ausência de efeitos do ambiente compartilhado (segunda lei) e a magnitude dos efeitos do ambiente único (terceira lei), que é ilustrada matematicamente da seguinte forma: "genes 50\%, ambiente compartilhado 0\%, ambiente único 50\%” (Pinker, 2004, p. 514). No último capítulo, é mostrado como a arte está arraigada nas faculdades mentais e é um subproduto de três adaptações evolutivas: a ânsia por status, o prazer estético de vivenciar objetos e ambientes adaptativos e a habilidade de elaborar artefatos para atingir objetivos desejados.

Aproveitando-se dos dizeres de R. Storey de que a literatura tem três vozes, a do autor, a dos leitores e a da espécie, Pinker conclui o livro extraindo da literatura cinco textos que, para ele, revelam as lições da natureza humana como algo a ser encarado sem medo e aversão, mas com equilíbrio e discernimento. As obras citadas são: "The brain is wider than the sky", de E. Dickinson; "Harrison Bergson", de K. Vonnegut; "1984", de G. Orwell; "As aventuras de Huckleberry Finn", de M. Twain e "Enemies, a love story", de I. B. Singer.

Apesar de a leitura do livro ser árdua, pela quantidade de debates suscitados, o extenso trabalho de pesquisa do autor, oferece-nos uma gama de informações bastante pertinentes ao campo das ciências psicológicas. Infelizmente, Pinker parece não conhecer importantes teóricos da Psicologia Cognitiva como Edouard Claparède, Jean Piaget e outros (nenhuma vez citados) que poderiam enriquecer esse debate. De qualquer forma, o livro provoca sérias reflexões a respeito das implicações das novas descobertas da ciência sobre a biologia da mente, tanto no que se refere às teorias "politicamente corretas" do meio acadêmico, quanto aos programas educacionais, aos tratamentos médicos e às psicoterapias atuais.

Contudo, não podemos nos deixar guiar sem críticas pela tentação das propostas ambiciosas de Pinker e cair no outro extremo da tábula rasa, ou seja, no "biologismo radical" que teria o mesmo tom do pós-modernismo (que leva ao estruturalismo radical), tão criticado pelo próprio autor. "Tabula Rasa" consegue demonstrar logicamente a teoria de que a "alma" seria uma atividade de processamento de informação no cérebro, mas deixa a desejar na justificativa sobre os $50 \%$ de influência dos genes, $0 \%$ do ambiente compartilhado e $50 \%$ do ambiente único. Quer nos convencer que crescer em determinada família exerce pouco ou nenhum efeito sobre o intelecto e a personalidade, mas que não está tudo nos genes; cerca da metade da variação da personalidade, da inteligência e do comportamento provém de algo no ambiente: o acaso! A idéia de destino pode ser conciliada com a biologia! Todavia, essa hipótese da influência do acaso dá margem a várias interpretações, desde aquelas pautadas nos cálculos probabilísticos até as mais místicas. Quando parecia que o autor havia encontrado o caminho da explicação interacionista, ou seja, que é a interação entre a criança e o ambiente (a família, diz ele) que as afeta, ele muda de rota para adotar a explicação dos fatores advindos do acaso.

\section{Referência}

Pinker, S. (2004). Tábula Rasa. A negação contemporânea da natureza humana. São Paulo: Companhia das Letras.

Recebido em 10.03.2005

Aceito em 26.10.2005 